\title{
Traditional-Medical Knowledge and Perception of Pangolins (Manis sps) among the Awori People, Southwestern Nigeria
}

\author{
Durojaye A Soewu ${ }^{1 *}$ and Temilolu A Adekanola ${ }^{2}$
}

\begin{abstract}
Background: Animals have been used as medicinal resources throughout human history. Majority of wildlife used in traditional medicines is taken from the wild; hence demand by traditional medicine is a cause of overexploitation of wild animals. Indiscriminate use of endangered species portends grievous implications for biodiversity conservation. This study investigated the dynamics of the use of pangolin in trado-medicinal preparations amongst the Awori people.

Methods: Forty traditional Yorubic-medical practitioners (tymps) selected through stratified random-sampling technique were interviewed using open-ended questionnaires. Various aspects of the utilisation of pangolin in traditional medicinal practices were investigated. Data collected were analysed using simple frequencies and percentages.

Results: An average of 1.6 pangolins were utilised per tymp per month. About $43 \%$ of respondents contracted hunters for deliberate searches for the animals. More than $92 \%$ believed that pangolins' abundance is steadily decreasing. Above 97\% reported a continuous decline in the size of pangolin. Pangolin was used in treating 47 conditions. Situations accommodated included those that can be treated by orthodox medicine like rheumatism and venereal diseases as well as some that are out of range for orthodox medicine including kleptomania and good luck charms. Some substitute animals like gorilla are under a greater conservation threat than pangolin.

Conclusions: Utilisation of pangolin in traditional medicine has no consideration for sustainability. Awareness should be created on people as regards the implications of unsustainable depletion of medicinal resources. Efforts should be intensified on ex-situ breeding of pangolin while subjecting the scales and other parts to laboratory studies to determine the bioactive constituents.
\end{abstract}

\section{Introduction}

Throughout human history, and in practically every human culture which presents a structured medical system, animals have been used as medicinal resources for the treatment and relieve of a wide variety of human health challenges [1]. Some animals have also been used for religious and cultural purposes such as sacrifices for appeasing and invoking spirits and gods while some others have played important roles in magic rituals and mysticism [2-4]. Traditional medicine has been described by the World Health Organization (WHO) as

\footnotetext{
* Correspondence: durosoewu@hotmail.com

${ }^{1}$ Department of Biological Sciences, Covenant University, P.M.B 1023, Ota,

Ogun State, Nigeria

Full list of author information is available at the end of the article
}

one of the surest means to achieve total health care coverage for the world's population [5]. The World Health Organisation (WHO) stated that traditional medicine refers to health practices, approaches, knowledge and beliefs incorporating animal and mineral based medicines, spiritual therapies, manual techniques and exercises, applied singularly or in combination to treat, diagnose and prevent illnesses or maintain well-being $[6,7]$. Traditional medicine was further defined by WHO as the sum total of all knowledge and practices, whether explicable or not, used in diagnosis, prevention and elimination of physical, mental or social imbalance and relying exclusively on practical experiences and observations handed from generation to generation, whether verbally or in writing $[7,8]$. This practice of treating

\section{Ciomed Central}


human diseases by use of therapeutics obtained or ultimately derived from animals is called Zootherapy [9]. Zootherapy on the other hand is an important component of ethnozoology, which deals with the study of relationship between the human societies and the animal resources around them [10]. In modern societies, zootherapy constitutes an important alternative among many other known therapies practiced worldwide [11].

It was observed that many animal species have been over-exploited as sources of medicines for the folk medicine trade [12]. A vast majority of wildlife products used in traditional medicines is usually taken directly from the wild [13]. The demand created by traditional medicine has however been identified as one of the causes of the overexploitation of the wild population of numerous animal species. This indiscriminate use of wild animals, especially endangered species in all forms of traditional medicine is a cause of growing concern $[11,12]$. Poaching animals for their medicinal values has brought many of the wild species closer to extinction and necessitated their listing in the red data book [14]. It is thus evident that the soaring demand for their body parts for use in medicinal practices is one common dilemma facing all fauna species [15]. Obviously, continued depletion of medicinal wildlife resources not only embodies a challenge for conservation, but more importantly represents a serious threat to the health status of human population $[4,13]$.

In Africa, reliance on wildlife-based medicine stems partly on the one hand from the high cost of conventional medicine and the inaccessibility of modern health care facilities. It is also due on the other hand to the fact that traditional medicine is often deemed a more appropriate method of treatment [13]. Traditional African Medicine (TAM) is a holistic discipline involving extensive use of indigenous herbalism combined with some aspects of African spirituality [16]. A considerable number of people living in rural areas in Africa rely solely on traditional medicines for health care $[4,13]$. The basis for traditional medicines and the primary ingredients used by the traditional healers are wild animal and plant species. This practice is widespread in Africa, and market stalls selling plants and animal parts for medicines are common in both rural and urban markets in many African towns and cities [17]. Several authors have also recorded a wide variety of animals and their parts in sales for other parts of the world. In a study on animal based remedies in the semi-arid region of Northeastern Brazil, Alves et al (2011) [14] reported 51 medicinal animals distributed among 42 zoological families used to cure about 68 ailments. Twenty-four animal species used in 35 different medicinal purposes were documented in an ethnozoological study in Mount Abu wildlife sanctuary in India [10]. In a review,
Mahawar and Jaroli (2008) [18] identified 109 animal species with 270 uses in traditional medicine in different parts of India, while Ferreira et al (2009) [19] in another study in Crato and Juazeiro do Norte, Ceara, Brazil, recorded 31 animal species distributed among 21 families. A study in some markets in Isreal recorded 20 animal species which products were sold as traditional remedies [10].

There is no indication that the level of utilisation of medicinal wildlife resources for traditional medicine would diminish [13]. On the contrary, there is every reason to believe that the quantities of animals (and plants) required for traditional medicine would increase substantially in years to come as human population grow and acceptance of traditional medicine and natural products increases in the market. Moreso, the magic, superstition and dogma that surrounded traditional medicinal preparations are giving way to an understanding of the real basis of their curative power and consequently their social acceptance [4,13]. According to Alves et al $(2011)$ [14], the use of animals for medicinal purposes is part of a body of traditional knowledge which is increasingly becoming more relevant to discussions on conservation biology, public health policies, sustainable management of natural resources, biological prospection and patents. This utilisation of animals in zootherapeutic practices has little or no consideration for the conservation status of the faunistic resources as protected animals are also used indiscriminately $[15,20]$. More than sixty-six percent of the animal species utilised in zootherapy by the Garasiya people of Rajasthan in India are included in the IUCN Red Data List [10].

Regarding its global conservation status, pangolins are presently rated as near threatened on IUCN Red Data Book and listed in appendix II of CITES. All four African species are listed in Class B of the 1986 African Convention on Nature and Natural Resources while the three western African species of pangolins are protected in Nigeria under Schedule 1 of Decree No. 11 (1985): Control of International Trade in Endangered Wild Fauna and Flora[4,7].

As the market value of wildlife has escalated with increasing demand and decreasing supply, there has been a marked shift in hunting motives from primarily for subsistence to purely for trade purposes. The resultant over-hunting has exposed several species, most especially the mammals to increased the risk. Pangolin is one of the mammalian species most affected [21]. This vulnerability of mammals to high incidence of utilisation reflected in some previous studies. Fifty-eight percent of the animals documented by [10] were mammals while among the more than five taxa recorded in [19], mammals represented the second largest utilised group. 
The present study was designed primarily to compare the trend of utilisation for this species between different locations and amongst different peoples in the country. While the data in Soewu and Ayodele (2009) [7] dwelt primarily on the volume traded, the present study focused on the actual rate of utilisation as revealed by the traditional Yorubic medical practitioners. This rate of utilisation provides a useful index of the cropping pressure on populations of this animal in the wild. Also, in addition to some aspects examined in the previous study, questions were raised on complementary ingredients required for the preparations - some of which on their own may be of conservation interests - methods of preparation cum administration of the trado-medical remedies. It also identified possible wild animal substitutes with their parts that could be used successfully in place of pangolin.

\section{Methodology}

The study was conducted in Ifo, Ewekoro, Egbado South and Ado Odo/Ota Local Government areas in Ogun State, Nigeria (Figure 1) between December 2006 and March 2007. Ogun State is entirely in the tropics. Located in the Southwest zone of Nigeria with a total land area of 16,409.26 square kilometres, it is bounded on the West by the Benin Republic, on the South by Lagos State and the Atlantic Ocean, on the East by Ondo State, and on the North by Oyo and Osun States.

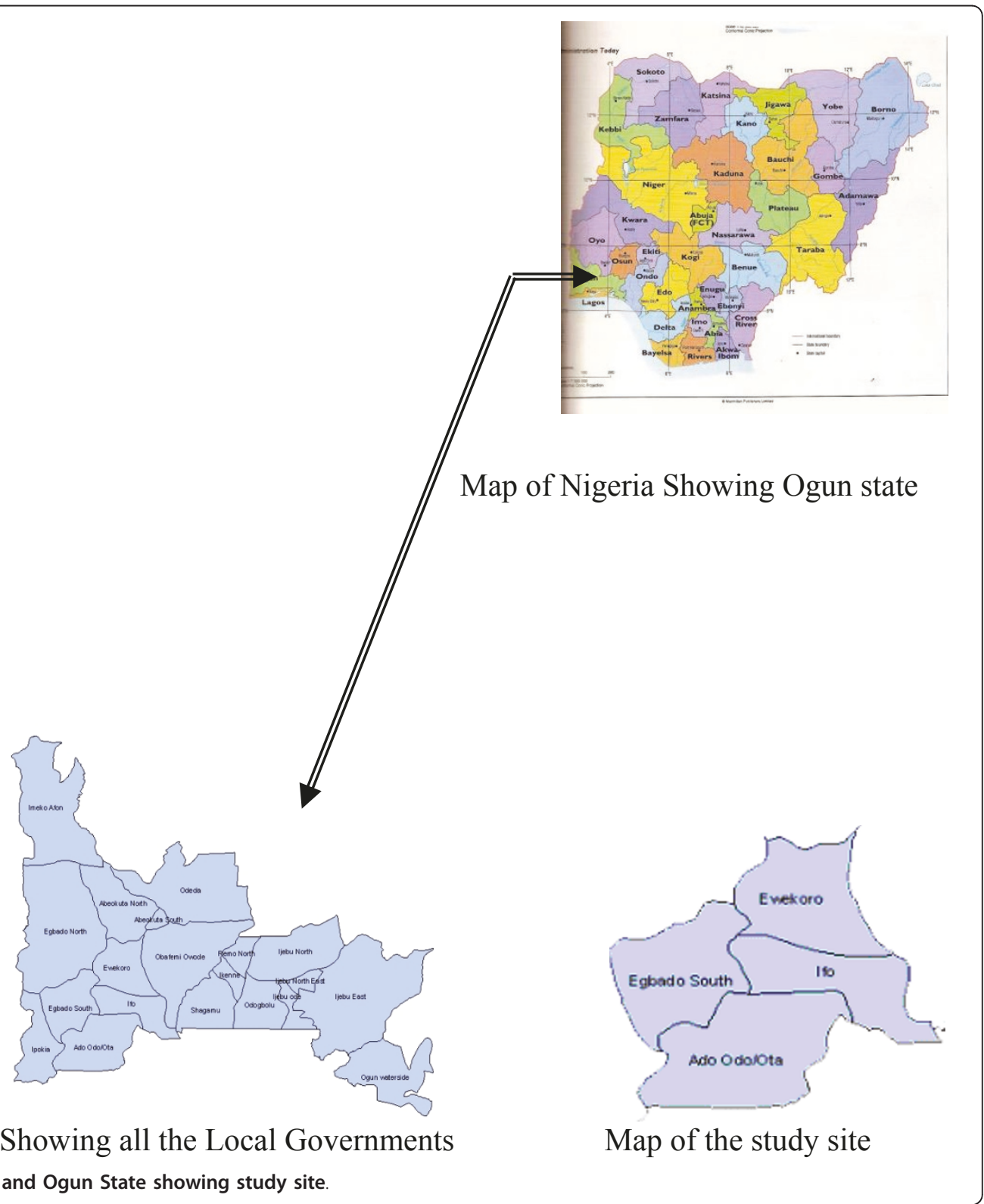


It is situated between Latitude $6.2^{\circ} \mathrm{N}$ and $7.8^{\circ} \mathrm{N}$ and Longitude $3.0^{\circ} \mathrm{E}$ and $5.0^{\circ} \mathrm{E}$. It has an estimated population of 3,486,683 people for the year 2005 [7].

\section{Survey}

Stratified random-sampling technique was employed to select the respondents throughout the study. Openended questionnaire was used to encourage maximum discussion and optimum extraction of information. A preliminary survey was conducted in December 2006 to standardise the questionnaire, determine the time required to completely administer one questionnaire and, establish contacts with the tymps association. Ten questionnaires were administered for the preliminary survey in all the Local Government Areas included in the study. During the main survey which spanned January-March 2007, questionnaires were administered on a total of 40 traditional Yorubic-medical practitioners (tymps) i.e 10 tymps in each Local Government Area. Questionnaires were administered on the tymps by direct interview method.

The study investigated the specific parts of pangolins employed to treat various conditions; complimentary ingredients required; method of preparation cum administration; need for accompanying incantations; and substitute wildlife species (and their parts) that could replace pangolin parts without necessitating a change in other ingredients. The quantity of pangolin utilised for the period as well as observable trends in size and availability of the animal were also examined. Demographic data were also collected on the practitioners. The survey was carried out in all the four local government areas simultaneously.

Three types of pangolins exist in West-Africa: the giant pangolin (Manis gigantea), the tree pangolins (Manis tricuspis) and the ground pangolin (Manis temminckii) [22].

Taxonomy, description, distribution and habitat, behavior, diet and reproduction for this animal is as presented in [7]. Although majority of its uses attributed to its scales and carcass, pangolins are also used in food as a supplementary protein source and as adornments $[4,7,23]$.

\section{Results and Discussion}

Eighty percent of respondents were aged between 46 and 75 years, 5.0 percent were above 75 years of age, only 15 percent were $36-45$ years old while none of them was younger than 36 years as shown in table 1 . Mean age for respondents was 58.5 years $(\mathrm{x}=58.5, \mathrm{n}=$ $40)$. Gender distribution of respondents showed that 90\% were males (table 1). Traditional medical practices dwells a lot on on-the-job experience. Table 2 shows that sixty-five percent of respondents had spent 26 years
Table 1 Age and gender distribution of respondents

\begin{tabular}{ccc}
\hline Age (in years) & Frequency & Percent \\
\hline $36-45$ & 6 & 15.0 \\
$46-55$ & 10 & 25.0 \\
$56-65$ & 12 & 30.0 \\
$66-75$ & 10 & 25.0 \\
$76-85$ & 2 & 5.0 \\
Total & 40 & 100.0 \\
Gender & & \\
Male & 36 & 90.0 \\
Female 4 & & 10.0 \\
\hline
\end{tabular}

or more on the healing practice, with mean duration in practice being 30.75 years $(x=30.75, n=40)$. Regarding the level of education of the respondents 22.5 percent had no formal education, 7.5 percent had exclusive quoranic education, and 55 percent had just primary education while only 5 percent had post secondary education as shown in table 3. Some respondents however combined quoranic with western education. As revealed in table 4 which depicts the source of the animal, 72.5 percent purchased pangolin from retail traders in the various markets, 25 percent bought from hunters while less than 3 percent cropped the animal directly from the wild. All respondents opined that all the pangolins they utilised, notwithstanding the point of procurement, came ultimately from populations in the wild. This agrees with the findings of Marshall (1998) [13] which reported that all plants and animals traded for traditional medicinal practices in South-Africa came from the wild. Also, [7] documented that all pangolins traded for and utilised in traditional medicinal practices by the Ijebus in Nigeria came from populations in the wild. Ten percent of respondents procured the animals by chance/on encounter, above $47 \%$ engaged in prepayment for pangolins; while about $43 \%$ claimed they contracted hunters or poachers for deliberate searches for the animals as shown in table 5 . Incidence of contract hunting is slightly higher in this study with 42.5 percent of respondents involved than in [7] which recorded only 14 percent. Contract hunting is employed whenever there is an urgent need for the animal, whole or parts, but which is not readily available in nearby markets.

Table 2 Duration in Practice

\begin{tabular}{ccc}
\hline Duration (in years) & Frequency & Percent \\
\hline $6-15$ & 5 & 12.5 \\
$16-25$ & 9 & 22.5 \\
$26-35$ & 10 & 25.0 \\
$36-45$ & 12 & 30.0 \\
$46-55$ & 4 & 10.0 \\
Total & 40 & 100.0 \\
\hline
\end{tabular}


Table 3 Level of Education of Respondents

\begin{tabular}{lcc}
\hline Level & Frequency & Percent \\
\hline None & 9 & 22.5 \\
Quoranic & 3 & 7.5 \\
Primary & 22 & 55.0 \\
Secondary & 4 & 10.0 \\
Post-secondary & 2 & 2.0 \\
Total & 40 & 100.0 \\
\hline
\end{tabular}

Table 4 Source of Animal

\begin{tabular}{ccc}
\hline Source & Frequency & Percent \\
\hline Direct cropping & 1 & 2.5 \\
Buy from hunters & 10 & 25.0 \\
Buy from retail dealers & 29 & 72.5 \\
Total & 40 & 100.0 \\
\hline
\end{tabular}

\section{Table 5 Mode of Procurement}

\begin{tabular}{ccc}
\hline Mode & Frequency & Percent \\
\hline By chance & 4 & 10.0 \\
Prepayment & 19 & 47.5 \\
Contract hunting & 17 & 42.5 \\
Total & 40 & 100 \\
\hline
\end{tabular}

High incentives often attached to contract hunting encourage poachers to push deeper into the natural habitat for this animal. In addition to depleting the population of the animal, this practice may inadvertently promote destruction of the habitat during desperate searches, thereby exposing individuals remaining in the population to further risks [7]. Table 6 presented the trends observed by respondents as regards the availability and size of pangolin. More than 92 percent believed that the availability of the animal in terms of its abundance is steadily decreasing with 5 percent yet to notice any difference in this trend. As regards the size, well above 97 percent claimed to have observed a continuous

Table 6 Trends in availability and size of pangolin

\begin{tabular}{lcc}
\hline Abundance & & \\
\hline Trend & Frequency & Percent \\
\hline Increasing & 1 & 2.5 \\
Decreasing & 37 & 92.5 \\
No difference & 2 & 5.0 \\
Total & 40 & 100.0 \\
\hline Size & & \\
\hline Trend & Frequency & Percent \\
Increasing & 0 & 0 \\
Decreasing & 39 & 97.5 \\
No difference & 1 & 2.5 \\
Total & 40 & 100.0 \\
\hline
\end{tabular}

Table 7 Quantity of Pangolin used per month

\begin{tabular}{ccc}
\hline Average number of pangolin used & Frequency & Percent \\
\hline 1 & 23 & 57.5 \\
2 & 12 & 30.0 \\
3 & 3 & 7.5 \\
4 & 2 & 5.0 \\
Total & 40 & 100.0 \\
\hline
\end{tabular}

decline over time in the size of pangolins they use. The quantity of pangolin utilised by the respondents over a period of one month is shown in table 7 . On the overall, 40 practitioners utilised 64 whole pangolins (Figure 2), giving an average of 1.6 animals per tymp per month.

Pangolin was used in treating a total of 47 conditions among the Aworis (table 8). The bone (from any part of the body), vertebral bones, eye, limbs and complete female reproductive organ were each used to treat a condition - rheumatism, stroke, kleptomania, fortune rouser and ejection of placenta respectively. Whole animal, flesh (in parts) and the complete thorax of pangolin were each employed in the treatment of 4 different conditions. A whole animal is required in the preparation of fortune rousers, immune boosters and rituals performed during the foundation laying stage of new buildings. A few pieces of pangolin carcass were used in divination and charms for good luck, protection and safety. Thorax was used to treat convulsions, unconsciousness, menstrual pains and in preventing or wading off rain. Whole internal organs of pangolin were used in preparing antidotes for food and sexual poisons while the full length tail was used to treat kleptomania and prepare charms to boost farm productivity. Pangolin head was used in the treatment of mental illness, kleptomania and in preparing good luck charms. The scale of pangolin was used to take care of 15 conditions which include stomach ulcers, venereal diseases, stroke, back pains, rheumatism, mental illness and as antibiotics. Scales were also used in preparation of medicine for safe parturition, increased productivity on the farm, wading off witches, protection and safety. Some situations required a combination of pangolin parts. Head and tip of the tail were combined in preparation of medicine for breakthrough in business, whole internal organs and complete limbs were used for money rituals while the head and scale were employed in medicine that confer protection against negative forces and their influences. The Aworis utilised pangolin extensively in traditional medicinal practices. Situations accommodated include those that can be treated by orthodox medicine as well as some that are out of range for orthodox medicine.

Diversity of conditions treated and parts employed in this study are similar in some cases to findings of some previous studies on trado-medicinal practices among 


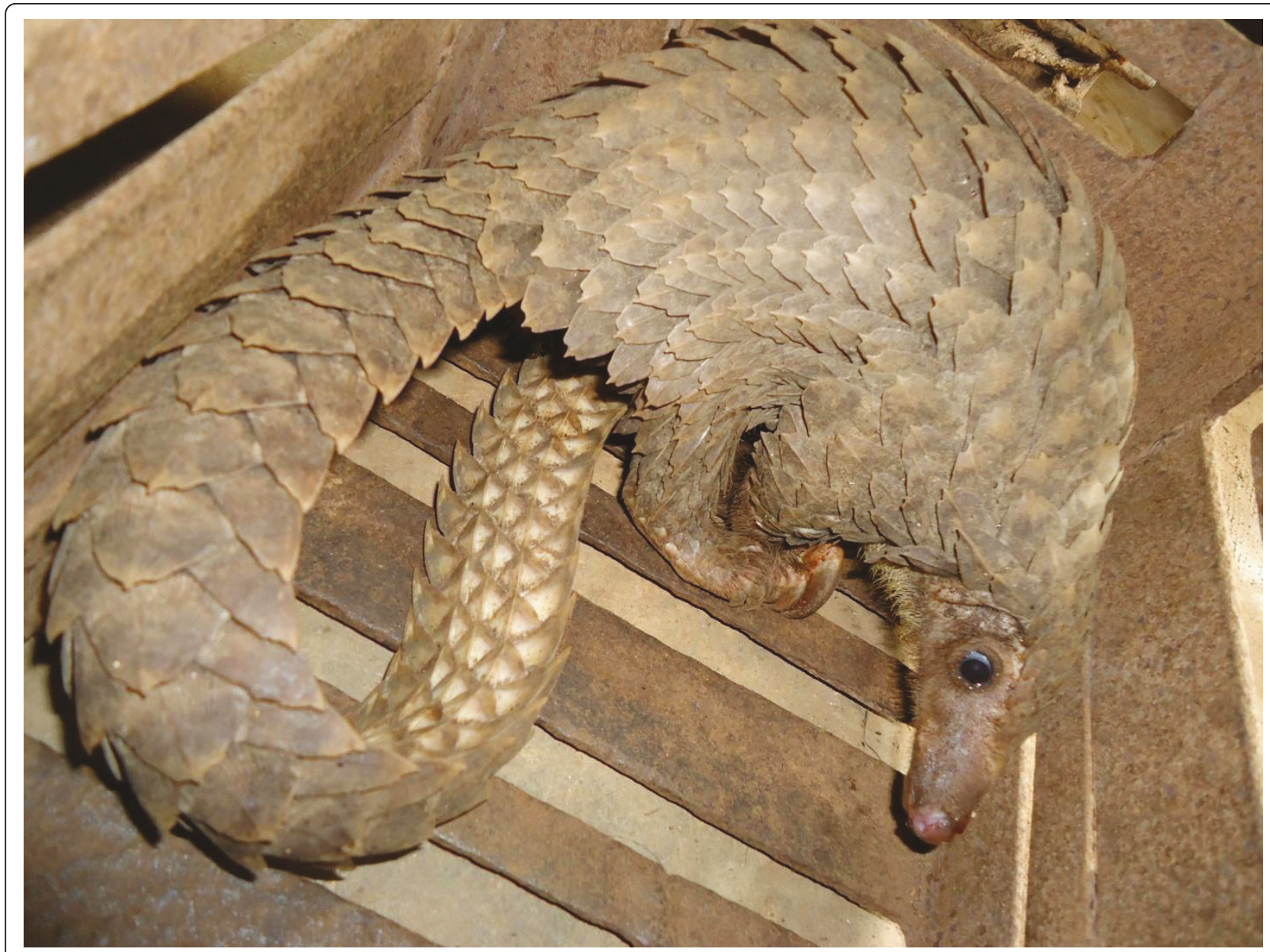

Figure 2 Live pangolin in a market stall.

other peoples. In previous single species studies, [24] reported that fat and egg of Podocnemis expansa were used to treat 16 different diseases while [7] reported the use of pangolin to treat 42 conditions amongst the Ijebus.

Traditional Yorubic medicine among the Ijebus used pangolin scales to treat stomach ulcers, venereal diseases, stroke, mental illness, to wade off witchcraft and to prepare traditional antibiotics as also recorded in this study. Other areas of similarities in uses between the Ijebus and the Aworis include the use of eyes to treat kleptomania, use of bones to treat rheumatism and stroke and, the utilisation of pangolin head for good luck charms. Some points of divergence in utilisation pattern between Ijebus and Aworis were recorded as there were some similar situations that required different parts of the animal. While the Ijebus used pangolin scale to prepare antidotes for sexual and food poisons, the Aworis in this study utilised whole internal organs of pangolins for such preparations. The Ijebus required the head to treat convulsions, but the Aworis would utilise the thorax for same purpose. Also the Ijebus will require a whole animal to prepare charms for breakthrough in business whereas the Aworis will employ the head and tip of tail for the same purpose.

The head of pangolin was used along with some other ingredients to treat kleptomania in this study. This agreed with [3] which stated that the head of white-bellied pangolin, Manis tricuspis, same species encountered in this study with the eyes intact was used in curing/ treating kleptomania. The whole animal was employed to cure/wade off bad illness and sickness while [1] reported that the scale was utilised to cure skin diseases. The thorax of pangolin was used to treat menstrual pain in this study but [25] reported that pangolin scales were believed to help regulate menstruation and stabilise breast milk secretion. Also the thorax of pangolin was used to wade off/prevent rain as against [7] which reported that the scales and blood were used for rain making and to protect against bad omen and prepare amulets against gun shots. Some group of people in East India utilised the scales for rheumatism and labour pain. 
Table 8 Part of pangolins used, conditions treated, complementary ingredients, method of preparation cum administration, and substitute animal

\begin{tabular}{|c|c|c|c|c|c|c|c|}
\hline $\begin{array}{l}\text { S/ } \\
\text { No }\end{array}$ & Parts used & $\begin{array}{l}\text { Conditions } \\
\text { Treated }\end{array}$ & Other Ingredients & Method of Preparation & Method of Administration & $\begin{array}{l}\text { Substitute } \\
\text { Animal }\end{array}$ & $\begin{array}{l}\text { Animal } \\
\text { Part }\end{array}$ \\
\hline 1 & Bone & Rheumatism & $\begin{array}{l}\text { A variety of leaves, } \\
\text { "iyere" }\end{array}$ & Made into concoction & To be taken once daily & None & \\
\hline 2 & Eye & Kleptomania & $\begin{array}{l}\text { Two whole pods of } \\
\text { Aframomum } \\
\text { melegueta }\end{array}$ & $\begin{array}{l}\text { Roasted, grinded into powdery } \\
\text { form }\end{array}$ & $\begin{array}{l}\text { Used to make incision on } \\
\text { the lower eyelids, left eye of } \\
\text { pangolin for making incision } \\
\text { on the left eyelid, ditto for } \\
\text { the right eye }\end{array}$ & Python & Eye \\
\hline 3 & $\begin{array}{l}\text { Female } \\
\text { reproductive } \\
\text { organ }\end{array}$ & $\begin{array}{l}\text { Ejection of } \\
\text { placenta }\end{array}$ & $\begin{array}{l}\text { A melegueta seeds, a } \\
\text { variety of leaves }\end{array}$ & $\begin{array}{l}\text { All ingredients are grinded into } \\
\text { powdery form }\end{array}$ & To be taken with pap & $\begin{array}{l}\text { Female } \\
\text { tortoise }\end{array}$ & $\begin{array}{l}\text { Whole } \\
\text { animal }\end{array}$ \\
\hline 4 & Flesh & $\begin{array}{l}\text { To confer } \\
\text { abilities for } \\
\text { divination }\end{array}$ & $\begin{array}{l}\text { A melegueta seeds, } \\
\text { leaf of "ori okan" }\end{array}$ & Made into concoction & To be ingested at once & $\begin{array}{l}\text { Wall gecko, } \\
\text { Parrot }\end{array}$ & $\begin{array}{l}\text { Whole } \\
\text { Flesh }\end{array}$ \\
\hline 5 & Flesh & Good luck & $\begin{array}{c}\text { A variety of leaves, } \\
\text { A melegueta seeds, } \\
\text { whole hare }\end{array}$ & Made into concoction & To be consumed all at once & None & \\
\hline 6 & Flesh & Protection & $\begin{array}{l}\text { A variety of leaves, } \\
\text { A melegueta seeds }\end{array}$ & Made into concoction & To be consumed all at once & $\begin{array}{l}\text { Whole } \\
\text { tortoise }\end{array}$ & Flesh \\
\hline 7 & Flesh & Safety & 'Oriji' leaves & Made into concoction & To be consumed all at once & None & \\
\hline 8 & Head & Good luck & $\begin{array}{l}\text { "Ire, aje, sawerepepe" } \\
\text { leaves, black soap }\end{array}$ & $\begin{array}{l}\text { Roasted, grinded into powdery } \\
\text { form, mixed with soap }\end{array}$ & Used to bath every morning & None & \\
\hline 9 & Head & Good luck & $\begin{array}{l}\text { Ficus exasperata } \\
\text { leaves, } 3 \text { pieces of } \\
\text { Cortiles colocynthis, } \\
3 \text { A melegueta pods }\end{array}$ & $\begin{array}{l}\text { All ingredients roasted, grinded } \\
\text { into powdery form. }\end{array}$ & $\begin{array}{c}\text { To be taken with solidified } \\
\text { pap i.e "eko" once every } \\
\text { Thursday }\end{array}$ & None & \\
\hline 10 & Head & Kleptomania & $\begin{array}{l}\text { Left arm of } \\
\text { chameleon }\end{array}$ & $\begin{array}{l}\text { Roasted, grinded into powdery } \\
\text { form }\end{array}$ & $\begin{array}{l}\text { Used to make incision on } \\
\text { the lower eyelids }\end{array}$ & None & \\
\hline 11 & Head & Kleptomania & $\begin{array}{l}\text { Human faeces } \\
\text { (of the client) }\end{array}$ & $\begin{array}{l}\text { Roasted, grinded into powdery } \\
\text { form }\end{array}$ & $\begin{array}{c}\text { Used to make incision on } \\
\text { lower eyelids and ingested } \\
\text { with water }\end{array}$ & Python & Head \\
\hline 12 & Head & Kleptomania & $\begin{array}{l}\text { "Alupaida" and } \\
\text { "Ewon pabida" leaves }\end{array}$ & $\begin{array}{l}\text { Roasted, grinded into powdery } \\
\text { form }\end{array}$ & $\begin{array}{l}\text { Used to make incision on } \\
\text { lower eyelids and ingested } \\
\text { with pap }\end{array}$ & Crab & Whole \\
\hline 13 & Head & Mental IIIness & $\begin{array}{c}\text { A variety of leaves } \\
\text { and roots, a chunk of } \\
\text { he-goat skull }\end{array}$ & $\begin{array}{l}\text { All ingredients grinded } \\
\text { together }\end{array}$ & To be consumed twice daily & Gorilla & Head \\
\hline 14 & $\begin{array}{l}\text { Head }+ \text { tip } \\
\text { of the tail }\end{array}$ & $\begin{array}{l}\text { Breakthrough in } \\
\text { business }\end{array}$ & $\begin{array}{l}\text { A variety of leaves, } \\
\text { soap }\end{array}$ & $\begin{array}{l}\text { Ingredients grinded, mixed } \\
\text { together with soap }\end{array}$ & $\begin{array}{l}\text { To be used to bath once in } \\
\text { a week }\end{array}$ & None & \\
\hline 15 & $\begin{array}{l}\text { Internal } \\
\text { organs }\end{array}$ & $\begin{array}{l}\text { Antidote for } \\
\text { food poison }\end{array}$ & Variety of leaves & Made into liquid mixture & To be drunk twice daily & None & \\
\hline 16 & $\begin{array}{l}\text { Internal } \\
\text { organs }\end{array}$ & $\begin{array}{l}\text { Antidote for } \\
\text { food poison }\end{array}$ & $\begin{array}{l}\text { Urine of a virgin } \\
\text { male/female }\end{array}$ & $\begin{array}{l}\text { Internal organs soaked in urine } \\
\text { for } 7 \text { days }\end{array}$ & $\begin{array}{c}\text { To be drunk and used to rub } \\
\text { the body }\end{array}$ & Cobra & $\begin{array}{l}\text { Internal } \\
\text { organs }\end{array}$ \\
\hline 17 & $\begin{array}{l}\text { Internal } \\
\text { organs }\end{array}$ & $\begin{array}{l}\text { To treat sexual } \\
\text { poison 'magun' }\end{array}$ & "Awogbaarun" roots & Made into decoction & $\begin{array}{c}\text { To be drunk immediately } \\
\text { after attack }\end{array}$ & None & \\
\hline 18 & Limbs & $\begin{array}{l}\text { Fortune } \\
\text { rouser }\end{array}$ & 7 A melegueta seeds & $\begin{array}{c}\text { All the limbs of a pangolin are } \\
\text { grinded with A melegueta seeds } \\
\text { and buried in a dump site for } 7 \\
\text { days, afterwards made into } \\
\text { concoction }\end{array}$ & To be consumed all at once & None & \\
\hline 19 & $\begin{array}{l}\text { Limbs+ } \\
\text { Internal } \\
\text { organs }\end{array}$ & $\begin{array}{l}\text { Money } \\
\text { rituals }\end{array}$ & $\begin{array}{l}16 \text { pieces of Ficus } \\
\text { exasperata } \\
\text { leaves,3 whole } A \\
\text { melegueta pods }\end{array}$ & $\begin{array}{l}\text { Leaves and A melegueta seeds } \\
\text { seeds grinded, used to cook } \\
\text { pangolin parts into concoction }\end{array}$ & To be consumed all at once & None & \\
\hline 20 & Scale & Good luck & $\begin{array}{l}\text { A melegueta seeds, } \\
\text { shaft of melon seeds }\end{array}$ & $\begin{array}{l}\text { Roasted, grinded into powdery } \\
\text { form }\end{array}$ & To be taken with pap & None & \\
\hline 21 & Scale & Back pain & $\begin{array}{c}\text { A melegueta seeds, } \\
\text { shea butter, some } \\
\text { leaves, "kafura } \\
\text { pelebe" }\end{array}$ & $\begin{array}{l}\text { Other ingredients grinded and } \\
\text { mixed with shea butter }\end{array}$ & $\begin{array}{l}\text { To be used to rub the back } \\
\text { twice daily }\end{array}$ & None & \\
\hline
\end{tabular}


Table 8 Part of pangolins used, conditions treated, complementary ingredients, method of preparation cum administration, and substitute animal (Continued)

\begin{tabular}{|c|c|c|c|c|c|c|c|}
\hline 22 & Scale & $\begin{array}{l}\text { Healing of } \\
\text { wounds/cuts }\end{array}$ & A melegueta seeds & $\begin{array}{l}\text { Roasted, grinded into powdery } \\
\text { form }\end{array}$ & $\begin{array}{l}\text { Powder sprinkled on the } \\
\text { cuts/wounds and covered } \\
\text { with a piece of cloth }\end{array}$ & None & \\
\hline 23 & Scale & $\begin{array}{l}\text { High } \\
\text { productivity on } \\
\text { the farm }\end{array}$ & $\begin{array}{l}\text { Goat fat, porcupine } \\
\text { spine }\end{array}$ & $\begin{array}{l}\text { All ingredients roasted and } \\
\text { grinded. }\end{array}$ & To be sprinkled on the farm & None & \\
\hline 24 & Scale & $\begin{array}{l}\text { High } \\
\text { productivity on } \\
\text { the farm }\end{array}$ & $\begin{array}{c}\text { Whole tortoise } \\
\text { Mucuna pruriens } \\
\text { seeds, a variety of } \\
\text { leaves }\end{array}$ & $\begin{array}{l}\text { All ingredients roasted and } \\
\text { grinded }\end{array}$ & To be sprinkled on the farm & None & \\
\hline 25 & Scale & Kleptomania & A melegueta seeds & $\begin{array}{l}\text { Roasted, grinded into powdery } \\
\text { form }\end{array}$ & To be taken with pap & None & \\
\hline 26 & Scale & Mental illness & Mainly incantations & $\begin{array}{l}\text { Scales grinded for use ( } 7 \text { pieces } \\
\text { for females and } 9 \text { for male) }\end{array}$ & $\begin{array}{c}\text { A single dose to be ingested } \\
\text { once daily with incantations } \\
\text { for } 16 \text { days }\end{array}$ & None & \\
\hline 27 & Scale & Rheumatism & $\begin{array}{c}\text { Shea butter, a variety } \\
\text { of leaves }\end{array}$ & $\begin{array}{l}\text { Other ingredients grinded and } \\
\text { mixed with shea butter cream }\end{array}$ & $\begin{array}{c}\text { To be used to rub affected } \\
\text { parts }\end{array}$ & Python & $\begin{array}{l}\text { Spinal } \\
\text { cord }\end{array}$ \\
\hline 28 & Scale & Stomach ulcer & $\begin{array}{l}\text { Dead earthworm } \\
\text { found on the road }\end{array}$ & Grinded into powdery form & To be taken with pap & None & \\
\hline 29 & Scale & Stroke & $\begin{array}{l}\text { A melegueta seeds, } \\
\text { a variety of leaves }\end{array}$ & $\begin{array}{l}\text { All ingredients grinded, made } \\
\text { into a decoction }\end{array}$ & To be drunk once daily & None & \\
\hline 30 & Scale & $\begin{array}{l}\text { Venereal } \\
\text { diseases }\end{array}$ & A variety of leaves & $\begin{array}{c}\text { Roasted, grinded into powdery } \\
\text { form }\end{array}$ & To be taken with hot water & None & \\
\hline 31 & Scale & $\begin{array}{l}\text { Wading off } \\
\text { witches }\end{array}$ & $\begin{array}{l}\text { Incense burner, } \\
\text { "Eepo obo", "eerun", } \\
\text { "imi ojo" }\end{array}$ & $\begin{array}{l}\text { All ingredients grinded and } \\
\text { poured in incense burner }\end{array}$ & Burnt as incense indoors & None & \\
\hline 32 & Scale (whole) & Safe delivery & $\begin{array}{c}\text { A melegueta seeds } \\
\text { and a variety of } \\
\text { leaves }\end{array}$ & $\begin{array}{l}\text { Roasted and grinded into } \\
\text { powdery form }\end{array}$ & To be taken with pap & Porcupine & $\begin{array}{l}\text { Spine } \\
\text { (whole) }\end{array}$ \\
\hline 33 & Scale & Good luck & $\begin{array}{c}\text { Bitter leaf, } A \\
\text { melegueta seeds, } \\
\text { "Oriji" leaves, local } \\
\text { soap }\end{array}$ & $\begin{array}{l}\text { All ingredients roasted, grinded, } \\
\text { mixed with soap }\end{array}$ & $\begin{array}{c}\text { To be used to bath every } 3 \\
\text { days }\end{array}$ & Male lizard & $\begin{array}{l}\text { Whole } \\
\text { animal }\end{array}$ \\
\hline 34 & Scale & $\begin{array}{l}\text { Aphrodisiacs/ } \\
\text { male potency }\end{array}$ & $\begin{array}{l}\text { A melegueta seeds, a } \\
\text { variety of leaves }\end{array}$ & $\begin{array}{l}\text { Roasted, grinded into powdery } \\
\text { form }\end{array}$ & $\begin{array}{l}\text { To be taken with pap } \\
\text { continously }\end{array}$ & None & \\
\hline 35 & $\begin{array}{l}\text { Scale } \\
\text { (whole), } \\
\text { head }\end{array}$ & Protection & $\begin{array}{l}\text { A melegueta seeds, } \\
\text { porcupine spine }\end{array}$ & $\begin{array}{l}\text { Roasted, grinded into powdery } \\
\text { form }\end{array}$ & To be ingested with pap & Cobra & $\begin{array}{l}\text { Head/ } \\
\text { whole } \\
\text { skin }\end{array}$ \\
\hline 36 & Scale & Antibiotics & $\begin{array}{l}\text { Hare carcass, gun } \\
\text { powder, "iyere", } \\
\text { "Kafura pelebe" }\end{array}$ & All ingredients grinded & To be taken with pap & None & \\
\hline 37 & Thorax & Convulsion & $\begin{array}{l}\text { A juvenile dog, } \\
\text { A melegueta seeds, } \\
\text { a variety of leaves }\end{array}$ & Made into concoction & To be consumed as soup & None & \\
\hline 38 & Thorax & Menstrual pain & $\begin{array}{l}\text { A whole crab, shrew, } \\
\text { Citrullus colocynthis, } \\
\text { 'iru' melon, 'ogiri' }\end{array}$ & $\begin{array}{l}\text { All ingredient cooked into } \\
\text { concoction }\end{array}$ & $\begin{array}{c}10 \text { oz to be drank } 3 \text { times } \\
\text { daily }\end{array}$ & None & \\
\hline 39 & Thorax & Unconsciousness & "Igi aaka" roots & Grinded into powdery form & To be swallowed with water & None & \\
\hline 40 & Thorax & $\begin{array}{l}\text { Wading off/ } \\
\text { preventing rain }\end{array}$ & $\begin{array}{l}\text { A whole A melegueta } \\
\text { pod, a variety of } \\
\text { leaves, a padlock }\end{array}$ & $\begin{array}{l}\text { All ingredients, grinded, packed } \\
\text { in a piece of rag, tied to the } \\
\text { padlock }\end{array}$ & $\begin{array}{l}\text { Incantation is recited on the } \\
\text { padlock, it is nailed to a tree }\end{array}$ & None & \\
\hline 41 & $\begin{array}{l}\text { Vertebral } \\
\text { bones }\end{array}$ & Stroke & $\begin{array}{l}\text { Riverside banana, } \\
\text { "ifon", roots "eru } \\
\text { alamo" }\end{array}$ & Cooked into concoction & To be taken 3 times daily & None & \\
\hline 42 & $\begin{array}{l}\text { Whole } \\
\text { animal }\end{array}$ & Building rituals & $\begin{array}{l}\text { Palm oil, Salt, "lyere", } \\
\text { "Olugelegele" leaves }\end{array}$ & $\begin{array}{c}\text { Blood is placed in a new plate, } \\
\text { and the whole flesh is divided } \\
\text { into } 16 \text { pieces }\end{array}$ & $\begin{array}{c}\text { Blood poured on the floor, } \\
\text { and flesh eaten as } \\
\text { concoction }\end{array}$ & None & \\
\hline 43 & $\begin{array}{l}\text { Whole } \\
\text { animal }\end{array}$ & Good fortune & $\begin{array}{l}\text { Sponge used to bath } \\
\text { a human corpse, a } \\
\text { whole pod of } A \\
\text { melegueta, "owo ara } \\
\text { tangiri" soap }\end{array}$ & $\begin{array}{l}\text { All ingredients grinded, mixed } \\
\text { with soap, poured in a } \\
\text { white container }\end{array}$ & $\begin{array}{c}\text { To be used to bath on } \\
\text { Sunday, } \\
\text { Monday, Tuesday }\end{array}$ & None & \\
\hline
\end{tabular}


Table 8 Part of pangolins used, conditions treated, complementary ingredients, method of preparation cum administration, and substitute animal (Continued)

\begin{tabular}{|c|c|c|c|c|c|c|}
\hline 44 & $\begin{array}{l}\text { Whole } \\
\text { animal }\end{array}$ & Prosperity & $\begin{array}{l}\text { A melegueta seeds, } \\
\text { black soap }\end{array}$ & $\begin{array}{l}\text { All ingredients grinded and } \\
\text { mixed with black soap }\end{array}$ & To be used to bath regularly & None \\
\hline 45 & $\begin{array}{l}\text { Whole } \\
\text { animal }\end{array}$ & $\begin{array}{c}\text { Wading off/ } \\
\text { curing bad } \\
\text { illness \& sickness }\end{array}$ & $\begin{array}{c}\text { A melegueta seeds, a } \\
\text { variety of leaves, } \\
\text { black soap }\end{array}$ & $\begin{array}{l}\text { Roasted, grinded into powdery } \\
\text { form, mixed with soap }\end{array}$ & To be used to bath regularly & None \\
\hline 46 & Whole tail & $\begin{array}{l}\text { High } \\
\text { productivity on } \\
\text { the farm }\end{array}$ & $\begin{array}{l}\text { Porcupine spine, } \\
\text { "jiwini", leaves } \\
\text { Mucuna pruriens } \\
\text { leaves "ekuru" }\end{array}$ & $\begin{array}{l}\text { All ingredients grinded into } \\
\text { powder }\end{array}$ & To be sprinkled on the farm & None \\
\hline 47 & Whole tail & Kleptomania & A variety of leaves & Grinded into powder & $\begin{array}{c}\text { Used to make incision on } \\
\text { the wrists and taken with } \\
\text { pap }\end{array}$ & None \\
\hline
\end{tabular}

The Chinese used the scales for preparations to neutralise witchcraft and evil spirits and to cure sores [7]. Scales were also employed in the present study to treat open cuts (sores) in the body.

The scale has the highest fidelity level in this study i.e. it is the most frequently utilised part in traditional medicinal preparations - a total 15 conditions were treated using the scales of pangolin. In addition to documenting pangolin scales as having the highest fidelity level, [25] also reported that South Korea imported a total of 29, $621 \mathrm{~kg}$ of pangolin scales valued at USD 471,000 from China, Vietnam, Indonesia and Singapore between 1993 and 1994 for use in the Traditional Korean medicine (TKM). In the present study, the scale was used for ejection of placenta in women after delivery but [3] reported that a whole female pangolin was required for the extrusion of placenta after parturition in women. The scales were also used to wade off witches among the Aworis and this agrees with [25] which reported that the scales were thought to neutralise witchcraft and evil spirits. It is worthy to emphasise here that the scales cannot by any means be extracted without killing the animal.

The utilisation of pangolin in treating the various conditions identified was found to be guided by a number of factors suggesting a unique co-evolution between medical, social and ecological systems. This agrees with some of the findings in Soewu (2008) [15]. The bioactive ingredients in some parts of this animal were responsible for some of their uses. Use of scales to treat wounds, stomach ulcer and venereal diseases is premised on antimicrobial potencies of preparations from the scale. Behavioral and ecological tendencies observed in the animal provided another guiding factor. The treatment of kleptomania with the eyes result from observed shyness in the animal. Some mythological conceptions about pangolin also influenced the use of some parts of the animal to treat some situations. Employment of female reproductive organs in preparations for safe delivery and ejection of placenta during childbirth arose from reasons that are apparently psychological or mystical. Preparations of medicines used as fortune rousers and to boost farm productivity were also found to dwell more on perceived mystical properties of this species.

An average of 1.6 pangolins utilised per tymp in a month is beyond the sustainable level for this species which requires at least two years attaining sexual maturity, gestation period of 150 days and has a litter size of just one. Although pangolin is presently not directly under the threat of extinction, it is listed in appendix II of CITES and schedule 1 the Nigeria's Endangered Species (Control of International Trade and Traffic) Decree No 11 1985. This requires that trade in this species must be regulated in order to avoid unsustainable utilisation of the species which may further worsen its conservation status. Findings during this study show that it is either the respondents have a total lack of awareness of the existence and implications of Decree No 11, or they know that the law is not enforced. With no record of successful captive breeding or domestication yet, especially in this part of the world, the only source of this animal is from populations in the wild that are already fast declining due to over-exploitation for medicinal uses [7]. This means a steady demand for a natural resource whose population size in the wild has not been established to be either adequate to cope with present demand or expanding appropriately to cope with likely increased demand in future.

Regarding the use of substitute animal, only 13 out of the 47 situations encountered during this study (27.7 percent) would readily accommodate another animal in place of pangolin. However, some of the animals identified as possible substitutes for pangolin are worse off regarding their conservation status as indicated in the various listings. Gorilla is actually listed on schedules I and 1 of CITES and Nigerian Decree No 11 respectively. Parrot and python occupy the same position as pangolin on these lists. Other substitute animals are not yet listed. This stresses the need for restraint when advocating the use of substitute animals in traditional medicines 
to avoid creating more conservation problems while trying to solve one.

The practitioners were often reluctant to disclose the full complement of ingredients required for some preparations. This might have stemmed from their attempt to safeguard the secrets of the healing art which is the only source of livelihood for virtually all of them and protect their heritage of several generations.

\section{Conclusion}

The use of this animal in traditional medicine is intensive and has no consideration for either the present conservation status of this species or the sustainability of such utilisation for the animal. There is a need to educate the entire citizenry on the implications of a total loss of this specie as a result of over-exploitation for biodiversity conservation and health care delivery. Traditional Yorubic-medical practitioners should be enlightened on the status of animals used in their tradomedical preparations. Most practitioners fail to realise that if these animals go into extinction, the lives of people who solely depend on traditional medicine would be at risk and their own trade may be adversely affected. If the trend of utilisation is not addressed sustainably, the practitioners of ethnomedicine would be at a greater risk of extinction than forests and other biomes in a manner akin to the current spasm of plant and animal extinction [14]. Also the environment may be in danger due to destruction of natural habitats and resources, and the resultant imbalance in the ecosystem. While advocating that the medicinal use of animals be considered together with other anthropogenic pressures, [14] observed that rapid reduction in natural resources as a consequence of the expanded urbanisation, global warming and reduced natural habitat poses a considerable threat to the sustainability of traditional medicine. It is very important for conservation groups to create adequate awareness as regards the implications of depletion of natural resources (flora and fauna) having known medicinal values.

A field study to assess the population dynamics of this animal in the wild is urgently required. According to [24] there is a need to increase our understanding of the biology and ecology of species commonly used as remedies to better assess the impacts of harvesting pressure (for medicinal and other purposes) on their wild populations. The report [24] stressed further that the general acceptance of zootherapy calls for an assessment of the impact of this healing method on wild populations. Efforts should also be intensified on ex-situ breeding projects to raise pangolins in captivity for the consumptive uses as well as re-introducing them into the wild. This may reduce the pressure on pangolin populations in the wild. The conservation of medicinal wildlife resources will require conservation, management, awareness, regulation and research initiatives by a whole range of institutions. Having recorded the highest fidelity level in previous studies as well this survey, there is need to subject scales as well as other parts of the various species of this animal to laboratory studies to determine the bioactive ingredients in them that makes pangolin so important medicinally all over the world.

\section{Acknowledgements}

The authors would like to thank all the Yorubic traditional medical practitioners interviewed especially Awise Hakeem Osijinrin, Chief S. Ishola Soewu and Late Apena Segun Ogunlana for their co-operation. We also thank Opeyemi Bakare and Jayeola Soewu for their contributions towards the preparation of this manuscript.

\section{Author details}

${ }^{1}$ Department of Biological Sciences, Covenant University, P.M.B 1023, Ota, Ogun State, Nigeria. ${ }^{2}$ Department of Plant Science and Applied Zoology, Olabisi Onabanjo University, Ago- Iwoye Ogun State, Nigeria.

\section{Authors' contributions}

DAS conceived of the study, participated in its design and coordination, review of literature and revision of the manuscript. TAA participated in data collection during the preliminary and main survey and in drafting the manuscript. Both authors read and approved the final manuscript.

\section{Competing interests}

The authors declare that they have no competing interests.

\section{Received: 5 April 2011 Accepted: 1 September 2011}

Published: 1 September 2011

\section{References}

1. Costa-Neto EM: Animal-based medicines: biological prospection and the sustainable use of zootherapeutic resources. An Acad Bras Ciênc 2005, 77(1):33-43.

2. Lev E: Traditional Healing with Animal (Zootherapy); Medieval to Present-Day Levantine Practice. Journal of Ethnopharmacology 2003, , 83: 107-118.

3. Sodeinde OA, Soewu DA: Pilot Study of the Traditional Medicine Trade in Nigeria. TRAFFIC Bulletin 1999, 18(1):35-40.

4. Soewu DA: Utilisation of Wild Animals in Traditional Medicine in Ogun State, Nigeria. Ph.D thesis Department of Wildlife and Fisheries Management, University of Ibadan, Nigeria; 2006, 220.

5. Adeola MO: Importance of wild animals and their parts in the culture, religious festivals, and traditional medicine, of Nigeria. Environmental Conservation 1992, 19(2):125-134.

6. World Health Organisation: Traditional Medicine. 2003 [http://www. worldhealthorganisation.com].

7. Soewu DA, Ayodele IA: Utilisation of Pangolin (Manis sps) in traditional Yorubic medicine in ljebu pronvince, Ogun State, Nigeria. Journal of Ethnobiol and Ethnomedicine 2009, 5:39[http://www.ethnobiomed.com/ content/5/1/39].

8. Adesina SK: Traditional Medical Care in Nigeria. 2007 [http://www onlinenigeria.com/links/LinksReadPrint.asp?blurb=574].

9. Costa Neto EM: Traditional use and sale of animals as medicines in Feira de Santana city, Bahia, Brazil. Indigenous knowledge and development monitor articles 1999, 7-2: 1-4.

10. Jaroli DP, Mahawar MM, Vyas N: An ethnozoological study in the adjoining areas of Mount Abu wildlife sanctuary, India. Journal of Ethnobiology and Ethnomedicine 2010.

11. Alves RN, Rosa IL: Why study the use of animal products in traditional medicines? Journal of Ethnobiology and Ethnomedicine 2005.

12. World Health Organisation (WHO): Traditional Medicine. 2000 [http://www. wpro.who.int/health_topics/traditional_medicine]. 
13. Marshall NT: Searching for a Cure: Conservation of Medicinal Wildlife Resources in East and Southern Africa. A TRAFFIC Species in Danger report 1998.

14. Alves RRN, Barbosa JAA, Santos SLDX, Souto WMS, Barboza RRD: Animalbased Remedies as Complementary Medicines in the Semi-arid Region of Northeastern Brazil. Evidence-Based Complementary and Alternative Medicine 2011, 1-15.

15. Soewu DA: Wild Animals in ethnozoological practices among the Yorubas of southwestern Nigeria and the implications for biodiversity conservation. African Journal of Agricultural Research 2008, 3(6):421-427 [http://www.academicjournals.org/AJAR].

16. Helwig D: Traditional African Medicine. Encyclopedia of Alternative Medicine 2007 [http://www.findarticles.com/p/articles/mi_g2603/is_0007/ ai_2603000708].

17. Ntiamoa-Baidu Y: West African Wildlife; a resource in jeopardy. Unasylva 1987, 39: 27-25.

18. Mahawar MM, Jaroli DP: Traditional zootherapeutic studies in India: a review. Journal of Ethnobiology Ethnomedicine 2008.

19. Ferreira FS, Brito SV, Ribeiro SC, Saraiva AAF, Almeida WO, Alves RRN: Animal-based folk remedies sold in public markets in Crato and Juazeiro do Norte, Ceara, Brazil. BMC Complementary and Alternative Medicine 2009, 9:1-18.

20. Mahawar MM, Jaroli DP: Traditional knowledge on zootherapeutic uses by the Saharia tribe of Rajasthan, India. Journal of Ethnobiology and Ethnomedicine 2007.

21. Newton P, Thai NV, Robertson S, Bell D: Pangolins in peril: using local hunters' knowledge to conserve elusive species in Vietnam. Endangered Species Research 2008, 6:41-53.

22. African Wildlife Fund (AWF): Pangolin. 2006 [http://www.awf.org/content/ wildlife/detail/pangolin].

23. Brautigam A, John $\mathrm{H}$, Tamsin $\mathrm{H}$, Jonathan $\mathrm{H}$ : Recent Information on the Status and Utilisation of African Pangolins. TRAFFIC Bullettin 1994, 15(1):15-22.

24. Alves RRN, Santana GG: Use and commercialization of Podocnemis expansa (Schweiger 1812) (Testudines: Podocnemididae) for medicinal purposes in two communities in North of Brazil. Journal of Ethnobiology and Ethnomedicine 2008, 4:1-6.

25. Kang S, Phipps M: A Question of Attitude: South Korea's Traditional Medicine Practitioners and Wildlife Conservation. A TRAFFIC East Asia Report 2003

doi:10.1186/1746-4269-7-25

Cite this article as: Soewu and Adekanola: Traditional-Medical Knowledge and Perception of Pangolins (Manis sps) among the Awori People, Southwestern Nigeria. Journal of Ethnobiology and Ethnomedicine 2011 7:25

\section{Submit your next manuscript to BioMed Central and take full advantage of:}

- Convenient online submission

- Thorough peer review

- No space constraints or color figure charges

- Immediate publication on acceptance

- Inclusion in PubMed, CAS, Scopus and Google Scholar

- Research which is freely available for redistribution 